\title{
Heterosis in crosses among white grain maize populations with high quality protein
}

\author{
Márcio Costa Rodrigues ${ }^{(1)}$, Lázaro José Chaves ${ }^{(2)}$ and Cleso Antônio Patto Pacheco(3)
}

\begin{abstract}
(1)Embrapa Amapá, Caixa Postal 10, CEP 68903-000 Macapá, AP. E-mail: marcio@cpafap.embrapa.br (2)Universidade Federal de Goiás, Escola de Agronomia e Engenharia de Alimentos, Caixa Postal 131, CEP 74001-970 Goiânia, GO. E-mail: Ichaves@agro.ufg.br (3)Embrapa Milho e Sorgo, Caixa Postal 151, CEP 35700-970 Sete Lagoas, MG. E-mail: cleso@cnpms.embrapa.br
\end{abstract}

\begin{abstract}
The objective of this work was to investigate heterosis and its components in 16 white grain maize populations presenting high quality protein. These populations were divided according to grain type in order to establish different heterosis groups. The crosses were carried out according to a partial diallel cross design among flint and dent populations. Seven agronomic traits were evaluated in three environments while four leaf diseases and incidence of corn stunt were evaluated in one. Least square procedure was applied to the normal equation $X^{\prime} X \beta=X^{\prime} Y$, to estimate the model effects and their respective sum of squares. Among the heterosis components, in diallel analysis, significance for average heterosis in grain yield, number of days to female flowering and to all evaluated diseases was detected. Specific heterosis was significant for days to female flowering and resistance to Puccinia polysora. Results concerned to grain yield trait indicate that populations with superior performance in dent group, no matter what flint population group is used in crosses, tend to generate superior intervarietal hybrids. In decreasing order of preference, the dent type populations CMS 476, ZQP/B 103 and ZQP/B 101 and the flint type CMS 461, CMS 460, ZQP/B 104 and ZQP/B 102 are recommended to form composites.
\end{abstract}

Index terms: Zea mays, partial diallel, general combining ability.

\section{Heterose em cruzamentos entre populações de milho de grãos brancos com alta qualidade protéica}

\begin{abstract}
Resumo - O objetivo deste trabalho foi investigar a heterose e seus componentes em 16 populações de milho de grãos brancos, de alta qualidade protéica. Estas populações foram divididas de acordo com o tipo de grão, para estabelecer grupos heteróticos diferentes. Os cruzamentos foram realizados entre populações dentadas e duras, seguindo o esquema dialélico parcial. Sete caracteres agronômicos foram avaliados em três locais, e quatro doenças foliares e a incidência de enfezamento, em um. O procedimento de quadrados mínimos foi aplicado à equação normal $X^{\prime} X \beta=X^{\prime} Y$, para estimar os efeitos do modelo e suas respectivas somas de quadrados. Entre os componentes de heterose, na análise dialélica, detectou-se significância para heterose média em dias para o florescimento feminino e resistência a Puccinia polysora. As populações com performance superior no grupo dentado, independentemente da população dura usada no cruzamento, tendem a gerar híbridos intervarietais de produtividade superior. Na formação de compostos, são recomendadas as populações CMS 476, ZQP/B 103 e ZQP/B 101, do tipo dentado, e CMS 461, CMS 460, ZQP/B 104 e ZQP/B 102, do tipo duro, nesta ordem.
\end{abstract}

Termos para indexação: Zea mays, dialelo parcial, capacidade geral de combinação.

\section{Introduction}

Maize is a vital food source in many areas of the developing world, particularly in poor rural communities. Its cropping in poor countries spread rapidly because of the robustness and high adaptability of maize to a wide range of environments. Maize is the staple food for people of many Latin America countries while in industrialized ones it is used mainly as animal feed.
Protein content in maize grains is about 9.5\%, and approximately 42 million tons of maize protein produced account for $15 \%$ of the world protein production (National..., 1988).

However, zein - the main maize grain protein - is poor in lysine and triptophan and presents low digestibility. Consequently, the cereal has lower protein quality for monogastric animal nutrition in comparison to other sources. The Opaque $2\left(o_{2}\right)$ gene increases significantly 
the lysine and triptophan contents in the endosperm (Mertz et al., 1964), but expresses negative pleiotropic effects on the grain quality, such as lower density, susceptibility to pests and diseases and a floury appearance (Vasal, 1994).

The International Maize and Wheat Improvement Center (CIMMYT) sought to solve these problems introducing modifier genes for denser and vitreous endosperm. Improved populations, which were called QPM (Quality Protein Maize), presented protein with greater biological value as well as yield and agronomic characteristics closer to normal cultivars. The biological value of common maize protein is approximately equivalent to $40 \%$ of the biological value of milk protein, while for QPM maize this value is $90 \%$ (National..., 1988).

In Brazil, the QPM breeding program began in 1984 at Embrapa Milho e Sorgo, by introducing 23 populations. White grain populations were better than yellow grain ones both in yield and qualitative characteristics (Magnavaca et al., 1988). The improvement of these populations aimed at obtaining cultivars more adapted to Brazilian conditions and resulted in the release of commercial cultivars with white and yellow grains, and the BR 2121 double cross cultivar with yellow grains. Low heterosis among the populations bred by Embrapa was observed in diallel crosses (Guimarães et al., 1997).

In 1988, CMS 451 population was released as BR 451 - the first Brazilian QPM variety of maize. This choice was made considering both high yield and good agronomic characteristics associated with high quality grain protein. Grains of this population, when crushed, showed high samp yield, with both good quality and grain aspect suitable to make breads and pastes. Researches developed by Embrapa have shown that corn flour from BR 451 can be mixed with wheat flour without changes in organoleptic properties of these products (Peixoto et al., 1990). Naves et al. (2004) compared BR 451 with normal endosperm to maize BR 136 and rice-bean mixture. BR 451 was superior, regarding protein biological value, to BR 136, and similar to rice-bean mixture. So, they recommended the use of QPM maize in Brazilian official programs that aim at reducing malnutrition, particularly among poor children.

Vasal (1986) reported that heterosis exploitation in intervarietal crosses of QPM maize populations should be coupled with population breeding, to allow synthesis of a series of new hybrids at each cycle. An elite fraction represented by the recombination of few superior elite families would allow uniformity to increase, better hybrid performance, and also selection of families with good endosperm modifier stability, good quality protein and few ear health problems.

Reports on heterosis in high quality protein maize populations found in literature show that assessments have been generally carried out using few parents. These results did not suggest the existence of divergent groups involving the populations (Vasal et al., 1993a, 1993b).

The objective of this work was to investigate heterosis and its components in 16 white grain maize populations presenting high quality protein.

\section{Material and Methods}

Sixteen QPM populations with white grains from the germplasm bank of Embrapa Milho e Sorgo (CMS populations) and from Empresa Brasileira de Sementes Ltda. (EBS) (ZQP/B populations) were used. These populations were divided according to their grain type in order to establish two different heterosis groups. Group I involved eight dent grain populations and group II, eight flint populations (Table 1).

Crosses were carried out between the population groups, according to a partial diallel model design in the winter of 1997 at the EBS experimental station, in Rio Verde, State of Goiás. Populations from group 1 were used as males in crosses with the ones from group 2 . The crosses CMS $469 \times$ ZQP/B 104, CMS $469 \times$ ZQP/ B 106 and ZQP/B $103 \times$ ZQP/B 106 populations were unsuccessful.

Parental populations and $\mathrm{F}_{1}$ hybrids were evaluated in the 1997/1998 growing season in experimental areas at EBS in Rio Verde, State of Goiás, and Cravinhos, State of São Paulo, and at the Escola de Agronomia da Universidade Federal de Goiás (EA-UFG), in Goiânia, State of Goiás.

Table 1. White grain quality protein maize populations grouped according to grain type.

\begin{tabular}{lcccc}
\hline & Group 1 & & \multicolumn{2}{c}{ Group 2 } \\
\cline { 1 - 2 } \cline { 5 - 5 } Population & Origin & & Population & Origin \\
\hline CMS 450 & Pop. 63 & & CMS 452 & Pop. 62 \\
CMS 451 & Pop. 64 & & CMS 457 & Blanco Cristalino \\
CMS 459 & La Posta & CMS 460 & Obregon 7940 \\
CMS 469 & Templado Blanco Dentado & CMS 461 & Poza Rica 7940 \\
CMS 476 & Sintetic (6 lines) & CMS 462 & Guanacaste \\
ZQP/B 101 & - & ZQP/B 102 & - \\
ZQP/B 103 & Pop. 63 & ZQP/B 104 & - \\
ZQP/B 105 & Pop. 64 & ZQP/B 106 & - \\
\hline
\end{tabular}

${ }^{(1)}$ Dent-grain type. ${ }^{(2)}$ Flint-grain type. 
For each location, the joint analysis of complete block design experiments with common controls was performed according to Gomes (1990). The 16 parental populations, $61 \mathrm{~F}_{1}$ hybrids and two controls were distributed in four randomized complete block design experiments with four replications. The Z 8452 and BR 2121 hybrids were used as controls in all experiments. The Z 8452 control is an elite single cross hybrid from EBS with yellow grains and normal endosperm, which is recommended for high technology level cropping in tropical and subtropical areas with medium to high soil fertility. BR 2121 is a double cross hybrid with yellow grains with QPM endosperm released by Embrapa Milho e Sorgo. Each experimental plot consisted of a single five-meter-row with five plants per meter spaced $0.8 \mathrm{~m}$ in Rio Verde and Cravinhos and 0.9 m in Goiânia.

The following traits were evaluated: plant height $(\mathrm{PH})$; ear height (EH); percentage of broken plants (BP); percentage of lodged plants (LP); number of days until female flowering (FF); leaf diseases caused by Exserohilum turcicum (Et), Puccinia polysora (Pp), Physopella zeae $(\mathrm{Pz})$ and Phaesophaeria maydis (Pm), evaluated in accordance to the assessment scale provided by the Agroceres Health Guide (Agroceres, 1996); percentage of plants affected by corn stunt complex (CS) and grain yield (GY).

The assessed traits varied according to the experiment location as follow: Goiânia, PH, EH, BP, LP, Et, Pp, Pz, Pm, CS, and GY; Rio Verde, PH, EH, BP, LP, FF, and GY; Cravinhos, PH, EH, BP, LP, and GY.

Grain yield data were adjusted to the ideal 25 plants per plot stand by covariance analysis whenever the correction resulted in a decrease $\geq 10 \%$ in the residual mean square.

Partial diallel model adapted by Miranda Filho \& Geraldi (1984), from the complete diallel of Gardner \& Eberhart (1966), was used in the intergroup analysis. The adapted model is the following:

$\mathrm{Y}_{\mathrm{ij}}=\mu+\alpha \mathrm{d}+\frac{1}{2}\left(\mathrm{v}_{\mathrm{i}}+\mathrm{v}_{\mathrm{j}}\right)+\theta\left(\overline{\mathrm{h}}+\mathrm{h}_{\mathrm{i}}+\mathrm{h}_{\mathrm{j}}+\mathrm{s}_{\mathrm{ij}}\right)+\overline{\mathrm{e}}_{\mathrm{ij}}$,

where $\mathrm{Y}_{\mathrm{ij}}$ is the mean of the cross between the $\mathrm{i}^{\text {th }}$ variety of group 1 and the $j^{\text {th }}$ variety of group 2; $\theta=1$ and $\alpha=0$ for the crosses; for the parental varieties, $Y_{\mathrm{ij}}$ is substituted by $Y_{\mathrm{ii}}$ or $\mathrm{Y}_{\mathrm{jj}}$ for varieties of group 1 or 2, respectively; $\mathrm{i}=1,2, \ldots, \mathrm{I}$; and $\mathrm{j}=1$ ', 2', .., J. For $\mathrm{Y}_{\mathrm{ii}}, \alpha=1$ and $\theta=0$, and for $Y_{j j}, \alpha=-1$ and $\theta=0$; $d$ is half the difference between the means of the two groups of varieties; $\mu$ is average of the means of the two variety groups; $v_{i}$ and $v_{j}$ are variety effects from groups 1 and 2 , respectively; $\bar{h}$ is average heterosis of all crosses; $h_{i}$ and $h_{j}$ are variety heterosis effects relative to groups 1 and 2, respectively; $s_{i j}$ is specific heterosis of the cross between the $i^{\text {th }}$ variety of group 1 and $j^{\text {th }}$ variety of group 2; $\overline{\mathrm{e}}_{\mathrm{ij}}$ is average experimental error associated to the hybrid or parent means.

Least squares procedure was applied to the normal equation $X^{\prime} X \beta=X^{\prime} Y$, derived from the linear model $\mathrm{Y}=\mathrm{X} \beta+\varepsilon$, to estimate the model effects and their respective sum of squares. $\mathrm{Y}$ is the vector of the observed means; $\mathrm{X}$ is the information matrix of coefficient according to the adopted model; $\beta$ is the vector of parameters to be estimated and $\varepsilon$ is the experimental error vector. The following restrictions were adopted to solve the system of equations:

$\sum \hat{v}_{i}=\sum \hat{v}_{j}=\sum \hat{h}_{i}=\sum \hat{h}_{j}=0$. The general combining ability (GCA) of each population was calculated using the expression:

$\hat{g}_{i}=\frac{1}{2} \hat{v}_{i}+\hat{h}_{i}$ or $\hat{g}_{j}=\frac{1}{2} \hat{v}_{j}+\hat{h}_{j}$ where $g_{i}$ and $g_{j}$ are the effects of GCA of the $\mathrm{i}^{\text {th }}$ population in group 1 and $\mathrm{j}^{\text {th }}$ population in group 2 , respectively. The joint analysis of the diallel tables for the three locations was carried out according to Miranda Filho \& Vencovsky (1995).

\section{Results and Discussion}

Any breeding strategy for high protein quality germplasm cannot be accomplished without help of grain and protein quality analyses (Vasal, 1994). So, results from agronomic performance can only be used as an initial reference for a breeding study.

In Table 2, joint analyses of variance according to the adopted partial diallel model for agronomic traits are showed. The effects of varieties, varieties within dent group and average heterosis were significant for grain yield. This indicated presence of significant variability among the evaluated parental populations mainly in the dent group. Variety and specific heterosis were not significant, therefore, it can be stated that the average heterosis is the most important heterosis component in the studied material.

The interpretation given by Vencovsky (1970) to the complete model of Gardner \& Eberhart (1966) suggests that average heterosis depends on the existence of the dominance effects and of gene frequencies differences among the considered populations groups. Similarly, the 
variety heterosis depends on the existence of differences among gene frequencies of a variety in relation to the mean gene frequency of the parents in the same group. Thus, a significant average heterosis effect indicates divergence among the gene frequencies of the dent and flint population groups for the loci displaying dominance.

A recurrent selection program should lead to an increase in the heterosis among these populations if there would be an increase in gene frequency divergence. However, if such an increase is the same, both in direction and magnitude, in the two populations, the heterosis will remain unchanged, as stated by Hallauer \& Miranda Filho (1981).

Non-significant variety heterosis effects suggest absence of important differences among populations of similar grain type, since it is a consequence of similar gene frequency in loci expressing some dominance in these populations. Grouping varieties according to grain type was effective to form heterosis groups among the studied populations, and, within groups, there was a reasonable homogeneity of loci gene frequencies that display some dominance. These results indicate, therefore, that the hybrid performance is related to the mean of the parental populations in dent group.

In the combining ability, studies carried out with high protein populations from CIMMYT, it was observed that the average heterosis values were similar to those found in this study (Table 3), and that specific heterosis has little importance (Vasal et al., 1993a, 1993b; Pixley \& Bjarnason, 1993). Rodrigues \& Chaves (2002) presented similar results with yellow grain QPM populations evaluated in the same locations and years. According to Pixley \& Bjarnason (1993), the reasons for the low SCA importance are the non-partition of the lines in heterotic groups during their development and the lack of concern with heterosis during the QPM line development at CIMMYT.

The significant interaction of the variety, variety within dent group and average heterosis effects with locations for grain yield suggest that caution should be taken with germplasm adaptation during improvement of the studied germplasm. This is not a surprise because the regions involved are reasonably far apart and have different environmental conditions. Rodrigues \& Chaves (2002) presented the same results in relation to yellow grain QPM populations, since the environment effects were less pronounced in the flint varieties compared to the dent group under the conditions studied, as can be inferred from the significant variety $\mathrm{x}$ environment interactions. Significant interaction of the combining ability for grain yield in QPM was also reported by Pixley \& Bjarnason (1993) and Vasal et al. (1993a).

Table 2. Joint analysis of variance for grain yield (GY, $\mathrm{t} \mathrm{ha}^{-1}$ ), percentage of lodged plants (LP), percentage of broken plants (BP), plant height ( $\mathrm{PH}, \mathrm{m})$, ear height (EH, $\mathrm{m}$ ), and number of days until female flowering (FF) in white grain maize populations and hybrids with high quality protein, according to the partial diallel design with 16 white grain maize populations.

\begin{tabular}{|c|c|c|c|c|c|c|c|}
\hline \multirow[t]{2}{*}{ Source of variation } & \multirow[t]{2}{*}{$\mathrm{DF}^{(1)}$} & \multicolumn{6}{|c|}{ Mean square } \\
\hline & & GY & LP & BP & $\mathrm{PH}$ & EH & $\mathrm{FF}$ \\
\hline Varieties & 15 & $3.872^{* *}$ & $321.83^{* *}$ & $153.02^{* *}$ & $0.091^{* *}$ & $0.051^{* *}$ & $14.698^{* *}$ \\
\hline Group 1 (dent) & 7 & $7.342^{* *}$ & $459.09^{* *}$ & $258.42^{* *}$ & $0.154^{* *}$ & $0.074^{* *}$ & $22.214^{* *}$ \\
\hline Group 2 (flint) & 7 & 0.870 & 214.61 & 66.98 & $0.041^{* *}$ & $0.036^{* *}$ & $8.527^{* *}$ \\
\hline $\mathrm{G}_{1} \times \mathrm{G}_{2}$ & 1 & 0.597 & 111.51 & 17.47 & 0.002 & 0.000 & $5.085^{*}$ \\
\hline Var. $\mathrm{x}$ locations & $15(\mathrm{~L}-1)$ & $3.490^{* *}$ & $619.65^{* *}$ & 127.20 & $0.018^{*}$ & $0.016^{* *}$ & $4.306^{* *}$ \\
\hline $\mathrm{G}_{1} \times$ locations & $7(\mathrm{~L}-1)$ & $6.642^{* *}$ & $1003.20^{* *}$ & $177.03^{*}$ & $0.026^{* *}$ & $0.029^{* *}$ & $3.103^{* *}$ \\
\hline $\mathrm{G}_{2} \times$ locations & $7(\mathrm{~L}-1)$ & 0.781 & $271.67^{* *}$ & 91.28 & 0.009 & 0.006 & $5.844^{* *}$ \\
\hline $\mathrm{G}_{1} \times \mathrm{G}_{2} \times$ locations & (L-1) & 0.390 & $370.26^{*}$ & 29.84 & 0.020 & $0.033^{*}$ & 1.955 \\
\hline Heterosis & 61 & & & & & & \\
\hline Average Het. & 1 & $19.231^{* *}$ & 40.51 & 63.54 & 0.006 & 0.007 & $12.936^{* *}$ \\
\hline Het. Group 1 & 7 & 0.659 & 118.18 & 54.04 & 0.015 & 0.021 & $10.066^{* *}$ \\
\hline Het. Group 2 & 7 & 0.654 & 85.998 & 34.38 & 0.006 & 0.004 & $3.198^{* *}$ \\
\hline Specific Het. & 46 & 0.325 & 69.448 & 48.17 & 0.010 & 0.009 & $2.416^{* *}$ \\
\hline Av. Het. $\mathrm{x}$ locations & (L-1) & $9.864^{* *}$ & $1095.20^{* *}$ & 8.26 & 0.007 & 0.030 & 2.374 \\
\hline Het. G1 x locations & $7(\mathrm{~L}-1)$ & $1.693^{* *}$ & $321.168^{* *}$ & 40.43 & $0.025^{* *}$ & 0.013 & $3.724^{* *}$ \\
\hline Het. G2 x locations & $7(\mathrm{~L}-1)$ & 0.447 & 146.997 & 74.38 & $0.018^{* *}$ & 0.010 & 1.970 \\
\hline S. Het. x locations & $46(\mathrm{~L}-1)$ & 0.534 & $155.860^{*}$ & 70.15 & 0.012 & 0.008 & $3.227^{* *}$ \\
\hline Error/r & 297(L-1) & 0.502 & 111.278 & 71.95 & 0.008 & 0.008 & 0.960 \\
\hline
\end{tabular}

${ }^{(1)} \mathrm{L}$ : number of locals iqual to 3 , except for FF, where $\mathrm{L}$ was iqual to 2 . *and ${ }^{* *}$ Significant at 5 and $1 \%$ of probability by the $\mathrm{F}$ test, respectively. 
Regarding grain yield in the dent group, CMS 476 showed the largest variety effect and general combining ability (GCA) estimates, $0.770 \mathrm{t} \mathrm{ha}^{-1}$ and $0.840 \mathrm{t} \mathrm{ha}^{-1}$, respectively, which suggests that this population presents superiority in favorable alleles frequency, and is the most suitable for combination with flint group (Table 3). Further, the populations CMS $450\left(0.558 \mathrm{t} \mathrm{ha}^{-1}\right), \mathrm{ZQP} /$ B $103\left(0.420 \mathrm{t} \mathrm{ha}^{-1}\right), \mathrm{ZQP} / \mathrm{B} 101\left(0.232 \mathrm{t} \mathrm{ha}^{-1}\right)$ and ZQP/ B 105 (0.138 t ha-1) showed positive values of variety effect. The GCA values for these populations were low or a negatives, which suggests that favorable alleles frequencies were higher than the average, but they did not present good combinations with dent group. These results suggest that intrapopulational breeding strategies are the most suitable to them.

Among flint populations, the variety and heterosis effect were not significant, although one can accomplish a selection, based on variety effect, of the populations CMS $462\left(0.450 \mathrm{t} \mathrm{ha}^{-1}\right)$, CMS $460\left(0.387 \mathrm{t} \mathrm{ha}^{-1}\right)$ and CMS $452\left(0.337 \mathrm{t} \mathrm{ha}^{-1}\right)$.
Vasal et al. (1993a), in Central America, observed among some QPM populations higher GCA values for populations 63 (CMS 450, ZQP/B 103) and 64 (CMS 451, ZQP/B 105). Magnavaca et al. (1988) also observed the same populations and found they were the most yielding materials among 23 introductions in Brazil. These results are in agreement with the present study suggesting a wide adaptation of them to Brazilian conditions. Population 68 (CMS 469), indicated as a promising one in Mexico by Vasal et al. (1993b), did not show good performance.

Regarding the percentage of broken and lodged plants, the effects of varieties were significant as well as varieties within dent group, suggesting important differences only among varieties of dent group. According to negative variety effects in relation to lodged plants, the most desirable dent populations were CMS 469 and CMS 450, and to broken plants were CMS 476 and ZQP/B 101. Most of the effects and their components were significant when the female flowering trait was analyzed.

Table 3. Estimates of varieties effects (v) and general combining ability (g) for grain yield (GY, $\mathrm{t} \mathrm{ha}^{-1}$ ), percentage of lodged plants (LP), percentage of broken plants (BP), plant height $(\mathrm{PH}, \mathrm{m})$, ear height $(\mathrm{EH}, \mathrm{m})$, and number of days until female flowering (FF) from the joint analysis of variance ${ }^{(1)}$.

\begin{tabular}{|c|c|c|c|c|c|c|c|c|c|c|c|c|}
\hline \multirow[t]{2}{*}{ Population } & \multicolumn{2}{|c|}{ GY } & \multicolumn{2}{|c|}{ LP } & \multicolumn{2}{|c|}{$\mathrm{BP}$} & \multicolumn{2}{|c|}{$\mathrm{PH}$} & \multicolumn{2}{|c|}{ EH } & \multicolumn{2}{|c|}{ FF } \\
\hline & $\hat{v}$ & $\hat{g}$ & $\hat{v}$ & $\hat{g}$ & $\hat{v}$ & $\hat{g}$ & $\hat{v}$ & $\hat{g}$ & $\hat{v}$ & $\hat{g}$ & $\hat{v}$ & $\hat{g}$ \\
\hline & \multicolumn{12}{|c|}{ Dent-grain type } \\
\hline CMS 450 & 0.558 & -0.033 & -6.83 & 2.32 & 1.28 & 0.73 & 0.08 & 0.13 & 0.04 & 0.07 & -0.02 & 0.86 \\
\hline CMS 451 & -0.257 & -0.290 & 6.15 & 5.31 & 0.13 & 0.36 & -0.07 & -0.05 & -0.14 & 0.00 & -0.52 & 0.12 \\
\hline CMS 459 & -0.087 & -0.042 & -0.89 & 2.50 & -1.77 & -2.87 & 0.02 & 0.04 & 0.03 & 0.05 & 0.36 & 1.95 \\
\hline CMS 469 & -1.773 & -0.614 & -8.13 & -6.77 & 11.77 & 2.90 & -0.18 & -0.10 & -0.11 & -0.06 & -1.52 & -0.55 \\
\hline CMS 476 & 0.770 & 0.840 & 3.67 & -1.37 & -4.90 & -3.82 & 0.12 & 0.07 & 0.14 & 0.03 & 2.48 & -0.25 \\
\hline ZQP/B 101 & 0.232 & 0.047 & 3.10 & -1.65 & -4.25 & 1.44 & -0.02 & 0.03 & -0.02 & -0.02 & -0.89 & -0.41 \\
\hline ZQP/B 103 & 0.420 & 0.167 & 4.42 & 2.24 & -2.39 & -1.59 & 0.11 & 0.04 & 0.09 & -0.02 & 0.11 & 0.17 \\
\hline \multirow[t]{2}{*}{ ZQP/B 105} & 0.138 & -0.077 & -1.49 & -2.59 & 0.13 & 2.86 & -0.05 & -0.15 & -0.03 & -0.05 & -0.02 & -1.91 \\
\hline & \multicolumn{12}{|c|}{ Flint-grain type } \\
\hline CMS 452 & 0.337 & -0.075 & -3.12 & -0.84 & 1.01 & -1.01 & 0.05 & 0.04 & 0.06 & 0.04 & -0.95 & 0.24 \\
\hline CMS 457 & -0.488 & -0.192 & 2.20 & 0.54 & -4.15 & -1.49 & 0.02 & 0.01 & -0.07 & -0.01 & -0.33 & -0.31 \\
\hline CMS 460 & 0.387 & 0.140 & -1.94 & 0.93 & 4.56 & 0.55 & 0.05 & 0.04 & 0.08 & 0.03 & 0.05 & 0.63 \\
\hline CMS 461 & 0.061 & 0.235 & -3.50 & -0.10 & -2.55 & 0.79 & -0.01 & 0.03 & 0.03 & 0.02 & -0.08 & -0.04 \\
\hline CMS 462 & 0.450 & -0.240 & 0.95 & -5.99 & -5.79 & 0.31 & -0.01 & -0.06 & 0.00 & -0.03 & 0.80 & -0.58 \\
\hline ZQP/B 102 & 0.049 & 0.074 & -3.10 & 0.43 & 4.05 & 1.27 & -0.01 & -0.03 & 0.02 & -0.02 & -0.70 & -0.02 \\
\hline ZQP/B 104 & -0.214 & 0.115 & 8.44 & 3.30 & -1.15 & -1.25 & -0.06 & -0.03 & -0.02 & 0.01 & 2.05 & 0.75 \\
\hline ZQP/B 106 & -0.584 & -0.057 & 0.06 & 1.71 & 4.01 & 0.83 & -0.02 & 0.01 & -0.09 & -0.04 & -0.83 & -0.68 \\
\hline
\end{tabular}

${ }^{1)}$ Mean of varietal groups, deviation between varietal groups, average heterosis, and relative magnitude of average heterosis for GY were 5.815, $0.10,0.613$, and $10.54 \%$, respectively; for LP were $14.22,1.32,0.89$, and $6.25 \%$, respectively; for BP were $8.37,0.52,1.11$, and $13.26 \%$, respectively; for $\mathrm{PH}$ were $2.17,0.00,-0.01$, and $0.46 \%$, respectively; for $\mathrm{EH}$ were $1.14,0.00,-0.01$, and $1.00 \%$, respectively; for $\mathrm{FF}$ were 61.96 , $-0.28,-0.50$, and $0.81 \%$, respectively. 
Data on leaf diseases and corn stunt were collected only in Goiânia. The variety and average heterosis effects presented statistical significance for all leaf diseases and specific heterosis showed significance for Pp (Table 4).

Significant variability was detected when the percentage of plants affected by corn stunt was evaluated. The sources of variation among populations, between population groups and the average as well as among groups heterosis were significant (Table 4). The relative magnitude of average heterosis (27.63\%), as shown in Table 5, suggests importance of dominance effects on the expression of such trait.

Table 4. Analysis of variances related to resistance level to Puccinia polysora (Pp), Physopella zeae (Pz), Phaesophaeria maydis (Pm), and Exserohilum turcicum (Et), and percentage of plants affected by corn stunt (CS) according to the partial diallel design with 16 white grain maize populations in Goiânia, State of Goiás.

\begin{tabular}{|c|c|c|c|c|c|c|}
\hline \multirow[t]{2}{*}{ Source of variation } & \multirow[t]{2}{*}{$\mathrm{DF}$} & \multicolumn{5}{|c|}{ Mean square } \\
\hline & & $\mathrm{Pp}$ & $\mathrm{Pz}$ & $\mathrm{Pm}$ & Et & CS \\
\hline Varieties & 15 & $4.9379^{* *}$ & $1.1797^{* * *}$ & $3.5448^{* * *}$ & $1.9358^{* * *}$ & $245.5936^{* * *}$ \\
\hline Group 1 & 7 & $9.0492^{* * *}$ & $1.9344^{* *}$ & $3.9655^{* *}$ & $0.6464^{*}$ & $257.4551^{* *}$ \\
\hline Group 2 & 7 & $1.1547^{* *}$ & 0.5912 & $3.7575^{* *}$ & $2.3923^{* *}$ & $124.1724^{* *}$ \\
\hline G1xG2 & 1 & $2.6400^{*}$ & 0.0156 & 1.0000 & 0.7656 & $1012.5122^{* *}$ \\
\hline Heterosis & 61 & & & & & \\
\hline Average Het. & 1 & $18.8666^{* *}$ & $2.1157^{*}$ & $2.8199^{*}$ & $14.4244^{* * *}$ & $361.8880^{* *}$ \\
\hline Het Group 1. & 7 & 1.2924 & 0.1990 & 0.5856 & 0.4128 & $134.0857^{* * *}$ \\
\hline Het Group 2. & 7 & 0.2927 & 0.2331 & 0.6259 & 0.1927 & $166.8053^{* *}$ \\
\hline Specific Het. & 46 & $1.3527^{* *}$ & 0.2530 & 0.6194 & 0.5617 & 28.1770 \\
\hline Error & 258 & 0.4240 & 0.5250 & 0.4250 & 0.6240 & 40.6870 \\
\hline
\end{tabular}

${ }^{*}$ and ${ }^{* *}$ Significant at 5 and $1 \%$ of probability by the $\mathrm{F}$ test, respectively.

Table 5. Estimates of varieties effects (v) and general combining ability (g) for resistance level to Puccinia polysora (Pp), Physopella zeae (Pz), Phaesophaeria maydis (Pm), and Exserohilum turcicum (Et), and percentage of plants affected by corn stunt (CS) in Goiânia, State of Goiás.

\begin{tabular}{|c|c|c|c|c|c|c|c|c|c|c|}
\hline \multirow[t]{2}{*}{ Population } & \multicolumn{2}{|c|}{$\mathrm{Pp}$} & \multicolumn{2}{|c|}{$\mathrm{Pz}$} & \multicolumn{2}{|c|}{$\mathrm{Pm}$} & \multicolumn{2}{|c|}{ Et } & \multicolumn{2}{|c|}{$\mathrm{CS}$} \\
\hline & $\hat{v}$ & $\hat{g}$ & $\hat{v}$ & $\hat{g}$ & $\hat{v}$ & $\hat{g}$ & $\hat{v}$ & $\hat{g}$ & $\hat{v}$ & $\hat{g}$ \\
\hline & \multicolumn{10}{|c|}{ Dent-grain type } \\
\hline CMS 450 & -0.25 & -0.26 & -0.34 & 0.06 & 0.50 & 0.08 & -0.12 & -0.23 & 0.77 & -2.16 \\
\hline CMS 451 & -0.50 & 0.00 & -0.34 & -0.06 & 0.50 & -0.08 & -0.13 & -0.15 & 0.41 & -2.99 \\
\hline CMS 459 & -0.25 & -0.05 & 0.16 & -0.03 & 0.25 & 0.07 & -0.13 & -0.27 & 0.47 & 0.87 \\
\hline CMS 469 & 3.00 & 0.78 & -0.34 & -0.19 & 0.25 & 0.36 & 0.62 & 0.15 & -0.72 & 7.71 \\
\hline CMS 476 & -0.75 & -0.41 & 0.91 & 0.47 & -0.50 & -0.42 & -0.38 & -0.11 & -3.05 & -2.81 \\
\hline ZQP/B 101 & -0.75 & 0.07 & -0.09 & -0.22 & 0.25 & 0.46 & 0.13 & 0.43 & 3.00 & 0.18 \\
\hline ZQP/B 103 & -0.75 & -0.17 & 0.16 & -0.05 & -0.50 & -0.01 & -0.13 & 0.14 & 1.49 & -0.50 \\
\hline \multirow[t]{2}{*}{ ZQP/B 105} & 0.25 & 0.03 & -0.09 & 0.04 & -0.75 & -0.46 & 0.13 & 0.05 & -2.37 & -0.34 \\
\hline & \multicolumn{10}{|c|}{ Flint-grain type } \\
\hline CMS 452 & 0.66 & 0.12 & -0.13 & 0.03 & 0.00 & -0.08 & 0.66 & 0.30 & -6.33 & -2.05 \\
\hline CMS 457 & 0.41 & -0.07 & -0.38 & -0.04 & 1.00 & 0.08 & -0.09 & -0.14 & 4.69 & 0.20 \\
\hline CMS 460 & -0.09 & 0.16 & 0.63 & 0.04 & -0.25 & 0.27 & 0.16 & -0.08 & -1.90 & -0.30 \\
\hline CMS 461 & -0.59 & -0.32 & -0.13 & 0.09 & -0.75 & -0.33 & -0.09 & 0.12 & 4.29 & -0.26 \\
\hline CMS 462 & -0.09 & 0.10 & 0.13 & 0.04 & 0.25 & -0.02 & -0.34 & 0.08 & -9.21 & 0.31 \\
\hline ZQP/B 102 & 0.16 & 0.06 & 0.13 & -0.04 & -0.75 & -0.36 & 0.66 & 0.30 & -0.87 & 2.93 \\
\hline ZQP/B 104 & -0.09 & 0.09 & 0.12 & 0.12 & -0.50 & -0.03 & -0.34 & -0.23 & -5.08 & -0.43 \\
\hline ZQP/B 106 & -0.34 & -0.13 & -0.38 & -0.24 & 1.00 & 0.45 & -0.59 & -0.33 & 14.39 & -0.40 \\
\hline
\end{tabular}

(1)Mean of varietal groups, deviation between varietal groups, average heterosis, and relative magnitude of average heterosis for resistance level to Puccinia polysora were 3.20, 0.20, -0.61, and 19.12\%, respectively; for resistance level to Physopella zeae were 2.64, -0.02, -0.20 , and 7.57\%, respectively; for resistance level to Phaesophaeria maydis were 3.02, -0.12, 0.23, and 7.62\%, respectively; for resistance level to Exserohilum turcicum were $2.51,-0.11,0.53$, and $21.11 \%$, respectively; for percentage of plants affected by corn stunt were 9.61 , -3.98 , -2.66 , and $27.63 \%$, respectively. 
According to Miranda Filho \& Chaves (1991), the high variability expected in variety composites turns them quite adequate for using as base population in breeding programs. The number of composites that can be obtained from a certain number of varieties may restrict yield prediction and detection of the most promising ones. Therefore, these authors studied models related to grain yield means prediction and observed that GCA can be a good parameter for selection of varieties to form a composite. In Tables 3 and 5 it is shown the estimated GCA values ( $g_{i}$ or $g_{j}$ ) of the studied populations. By ranking the populations according to positive GCA for grain yield in a decreasing order, it pointed out CMS 476, ZQP/B 103 and ZQP/B 101 populations, within the dent group, and CMS 461, CMS 460, ZQP/B 104 and ZQP/ B 102, within the flint group. The estimates of the GCA effects regarding other traits are also shown in Tables 3 and 5. The use of each one of these traits in population selection will depend on the specific objectives of the program and the most relevant problems focused.

If a plant breeder wants a composite for use per se or as base in an intrapopulation recurrent selection program, the combination of flint and dent populations to form a composite can be recommended. In such a case, the additive gene action detected from the effects of varieties and the non-additive effects detected from the variety heterosis could be exploited. In programs designed to obtain inbred lines or in reciprocal recurrent selection programs, the composites should be formed only with populations that have the same grain type to maintain the heterosis groups. In these programs, the heterosis exploitation potential would be maximized when the hybrids among these composites are synthesized or the lines extracted from them are combined.

\section{Conclusions}

1. Dominance effects are important for grain yield and corn stunt.

2. Populations with superior performance in dent group tend to generate superior intervarietal hybrids, no matter what flint group population has been used in crosses.

3. The dent type CMS 476, ZQP/B 103 and ZQP/ B 101 populations and the flint type CMS 461, CMS 460, ZQP/B 104 and ZQP/B 102 should be recommended to form composites.

\section{Acknowledgements}

To Prof. Edward Madureira Brasil (EA/UFG), for his essential help in carrying out the experiments of this study in Goiânia.

\section{References}

AGROCERES. Guia de sanidade. São Paulo, 1996. 172p.

GARDNER, C.O.; EBERHART, S.A. Analysis and interpretation of the variety cross diallel and related population. Biometrics, v.22, p.439-452, 1966.

GOMES, F.P. Curso de estatística experimental. 13.ed. Piracicaba: Nobel, 1990. 467p.

GUIMARÃES, P.E.O.; LOPES, M.A.; GAMA, E.E.G.; SANTOS, M.X.; PARENTONI, S.N.; PAES, M.C.D.; VIEIRA JÚNIOR, P.A.; SILVA, A.E.; PAIVA, E.; CORRÊA, L.A.; PACHECO, C.A.P. Quality protein maize improvement at the National Maize and Sorghum Research Center CNPMS/EMBRAPA/BRAZIL. In: LARKINS, B.A.; MERTZ, E.T. (Ed.). Quality protein maize: 1964-1994. Ashland, OH, USA: Purdue University Press, 1997. p.185-203.

HALLAUER, A.R.; MIRANDA FILHO, J.B. Quantitative genetics in maize breeding. Ames: Iowa State University Press, 1981. 468p.

MAGNAVACA, R.; PAIVA, E.; WINKLER, E.I.; CARVALHO, H.W.L. de; SILVA FILHO, M.D.; PEIXOTO, M.J.V.V.D. Avaliação de populações de milho de alta qualidade protéica. Pesquisa Agropecuária Brasileira, v.23, p.1263-1268, 1988.

MERTZ, E.T.; BATES, L.S.; NELSON, O.E. Mutant gene that changes protein composition and increases lysine content of maize endosperm. Science, v.145, p.279-280, 1964.

MIRANDA FILHO, J.B. de; CHAVES, L.J. Procedures for selecting composites based on prediction methods. Theoretical and Applied Genetics, v.81, p.265-271, 1991.

MIRANDA FILHO, J.B. de; GERALDI, I.O. An adapted model for the analysis of partial diallel crosses. Revista Brasileira de Genética, v.7, p.677-688, 1984.

MIRANDA FILHO, J.B. de; VENCOVSKY, R. Analysis of variance with interaction of effects. Revista Brasileira de Genética, v.18, p.129-134, 1995.

NATIONAL RESEARCH COUNCIL. Quality protein maize. Washington: National Academy Press, 1988. 100p.

NAVES, M.M.V.; SILVA, M.S.; CERQUEIRA, F.M.; PAES, M.C.D. Avaliação química e biológica da proteína do grão em cultivares de milho de alta qualidade protéica. Pesquisa Agropecuária Tropical, v.34, p.1-8, 2004.

PEIXOTO, M.J.V.V.D.; PARENTONI, S.N.; GAMA, E.E.G.; MAGNAVACA, R.; PAIVA, E.; REGO, M.M. Perspectiva de utilização de milho de alta qualidade protéica no Brasil. Informe Agropecuário, v.14, p.23-24, 1990.

PIXLEY, K.V.; BJARNASON, M.S. Combining ability for yield and protein quality among modified-endosperm opaque-2 
tropical maize inbreds. Crop Science, v.33, p.1229-1234, 1993.

RODRIGUES, M.C.; CHAVES, L.J. Heterosis and its components in crosses among high quality protein maize populations. Crop Breeding and Applied Biotechnology, v.2, p.281-290, 2002.

VASAL, S.K. Approaches and methodology in the development of QPM hybrids. In: CONGRESSO NACIONAL DE MILHO E SORGO, 15., 1984, Maceió. Proceedings. Brasília: Embrapa-DDT, 1986. p.419-430.

VASAL, S.K. High quality protein corn. In: HALLAUER, A.R. (Ed.). Speciality corn. Flowery: CRC, 1994. p.79-121.
VASAL, S.K.; SRINIVASAN, G.; PANDEY, S.; GONZALÉZ, F.; CROSSA, J.; BECK, D.L. Heterosis and combining ability of CIMMYT's quality protein maize germplasm: I. Lowland tropical. Crop Science, v.33, p.46-51, 1993a.

VASAL, S.K.; SRINIVASA, G.; PANDEY, S.; GONZALÉZ, F.; CROSSA, J.; BECK, D.L. Heterosis and combining ability of CIMMYT's quality protein maize germplasm: II. Subtropical. Crop Science, v.33, p.51-57, 1993b.

VENCOVSKY, R. Alguns aspectos teóricos e aplicados relativos a cruzamentos dialélicos de variedades. 1970. 59p. Tese (Doutorado) - Escola Superior de Agricultura Luiz de Queiroz, Piracicaba.

Received on November 12, 2004 and accepted on June 8, 2005 